\title{
PERLINDUNGAN HUKUM BAGI KONSUMEN MELALUI PENYELESAIAN SENGKETA AKIBAT JANJI IKLAN PERUMAHAN
}

\author{
NINIEK WAHYUNI \\ Fakultas Hukum Universitas Kadiri \\ Jalan Selomangleng Nomor 1 Kediri \\ Email : niniek_wahyuni@unik-kediri.ac.id
}

\begin{abstract}
ABSTRAK
Rumah merupakan kebutuhan pokok manusia. Menangkap peluang kebutuhan akan rumah, developer ikut berperan dalam pemenuhan kebutuhan tersebut. Untuk menarik minat konsumen, supaya membeli produknya, salah satu cara yang digunakan developer dalam menawarkan rumahnya adalah melalui iklan. Namun, seringkali iklan yang disampaikan tidak jujur dan bahkan dapat menimbulkan kerugian kepada konsumen. Oleh karena itu, konsumen perlu mendapat perlindungan hukum. Konsumen yang menderita kerugian akibat janji iklan yang tidak sesuai, dapat mengajukan gugatan kepada developer, dan menyelesaikan sengketanya baik melalui jalur di luar pengadilan, maupun melalui pengadilan.
\end{abstract}

Key Words : Perlindungan Hukum, Konsumen, Iklan, Penyelesaian Sengketa.

\section{Latar Belakang Masalah}

Perumahan merupakan salah satu kebutuhan dasar manusia (Basic Need). Seiring dengan bertambahnya jumlah penduduk yang makin pesat, kebutuhan terhadap perumahan juga telah mengalami peningkatan. Hal tersebut mendorong pihak pemerintah maupun swasta untuk melaksanakan pembangunan perumahan.

Rumah menjadi sarana bagi manusia untuk melakukan berbagai macam aktifitas hidup dan sarana untuk memberikan perlindungan utama terhadap adanya gangguangangguan eksternal, baik terhadap kondisi iklim maupun terhadap gangguan lainnya. Saat ini konsep perumahan telah mengalami pergeseran, tidak hanya sebagai kebutuhan dasar saja, ataupun sebagai media yang memberikan perlindungan, namun perumahan telah menjadi gaya hidup (life style), memberikan kenyamanan dan menunjukkan 
karakteristik atau jati diri, yang merupakan salah satu pola pengembangan diri serta sarana private, sebagaimana dibutuhkan pada masyarakat global. ${ }^{1}$

Semakin meningkat kebutuhan akan perumahan, menarik minat pengembang perumahan untuk ikut berperan serta dalam pemenuhan kebutuhan akan perumahan dan berusaha untuk mendapatkan keuntungan dari usaha tersebut. Untuk memberikan informasi kepada masyarakat atau konsumen perumahan, banyak cara dilalukan oleh pengembang, salah satu adalah dengan cara beriklan, baik melalui media Televisi, Koran, maupun Brosur.

Informasi yang disampaikan oleh pelaku usaha, biro iklan dan media iklan seringkali hanya menyampaikan yang baik-baik saja dan tidak menyampaikan yang lengkap, bahkan cenderung menyesatkan konsumen. Iklan tersebut sangat merugikan konsumen, karena kebohongan yang dilakukan oleh pelaku usaha. Apa yang tertera dalam iklan tidak sesuai dengan kondisi barang yang ada.

Konsumen berada pada posisi yang dirugikan. Permasalahan tersebut merupakan persoalan yang klasik dalam suatu sistem ekonomi, terutama pada negara-negara berkembang, karena perlindungan terhadap konsumen belum menjadi prioritas utama dalam dunia bisnis, melainkan keuntunganlah yang menjadi prioritas utama bagi pelaku usaha, tidak terkecuali dalam bidang perumahan. ${ }^{2}$

Merebaknya kasus perumahan dalam bisnis properti atau perumahan, pada dasarnya, diawali dengan adanya ketidak sesuaian antara apa yang tercantum dalam brosur atau iklan berupa informasi produk, dengan realita yang didapatkan. Tidak mudah mengharapkan kesadaran pelaku usaha yang pada dasarnya secara prinsip ekonomi lebih mengutamakan untuk mendapat keuntungan yang semaksimal mungkin, dengan modal seminim mungkin. Prinsip ini sangat potensial merugikan kepentingan konsumen, baik secara langsung maupun tidak langsung. ${ }^{3}$

Maraknya pengaduan konsumen perumahan, merupakan cermin bahwa belum adanya kesadaran di kalangan developer/pengembang perumahan bahwa kalau konsumen membayar, mereka berhak mendapatkan rumah sesuai dengan yang dijanjikan pengembang dalam iklan/brosur/pameran perumahan.

\footnotetext{
${ }^{1}$ Miru, A dan Sutarman, Y. 2004. Hukum Perlindungan Konsumen, Raja Grafindo Persada, Jakarta, h. 24.

2 Purwadi, A. 1992. Aspek Hukum Perdata Pada Perlindungan Konsumen. Surabaya: Yuridika, Fakultas Hukum Universitas Airlangga, h. 41.

${ }^{3}$ Ibid, h.36.
} 


\section{Rumusan Masalah}

Berdasarkan latar belakang masalah tersrbut, permasalahan yang akan dibahas dalam tulisan ini adalah Perlindungan Hukum Bagi Konsumen Perumahan Melalui Penyelesaian Sengketa Akibat Iklan yang Menimbulkan Kerugian.

\section{Metode Penelitian}

Dalam setiap penulisan karya ilmiah penggunaan metode penelitian merupakan salah satu persyaratan agar supaya diperoleh hasil penelitian sesuai dengan permasalahan yang dikemukakan, sehingga dengan demikian untuk dapat menjawab permasalahan dalam penulisan karya ilmiah ini tipe penelitian yang penulis gunakan adalah Yuridis Normatif. Penulisan karya ilmiah ini dilakukan berdasarkan pada prosedur ilmiah sehingga dapat menjawab permasalahan, memahami hukum yang terkandung dalam norma dan kaidah dari sudut pandang teori dan keilmuan hukum.

Dalam tipe penelitian yuridis normatif ini pendekatan masalah yang penulis gunakan adalah pendekatan perundang-undangan. Pendekatan perundang-undangan digunakan dalam penulisan karya ilmiah ini dikarenakan fokus dari penelitian adalah mengkaji bagaimana perlindungan hukum bagi konsumen perumahan akibat iklan yang menimbulkan kerugian berdasarkan pada ketentuan UU Perlindungan Konsumen (UUPK) serta upaya penyelesaian sengketanya baik melalui litigasi maupun non litigasi.

\section{Pembahasan}

\subsection{Pengaturan Periklanan di Indonesia.}

Pengaturan iklan secara tegas, tidak saja menjamin perlindungan hukum terhadap konsumen, tetapi pengaturan tersebut juga sangat bermanfaat sebagai pedoman bagi para pihak yang terlibat dalam kegiatan periklanan, yaitu: Pengiklan, perusahaan periklanan, dan media penyiar iklan dalam melakukan kegiataannya. Melalui peraturan atau regulasi yang ada, diharapkan produk iklan yang dihasilkan penuh muatan kreativitas namun tetap menjunjung asas-asas umum periklanan serta aturan hukum yang ada. Meskipun secara khusus belum mempunyai Undang-undang Periklanan, namun ketentuan tentang periklanan telah terdapat dalam Kode Etik dan beberapa peraturan yang berlaku.

Asas-asas Umum Tata Krama dan Tata Cara Periklanan Indonesia berdasarkan Etika Penyiaran Indonesia (EPI) adalah: 
a. Iklan harus jujur, bertanggung jawab, dan tidak bertentangan dengan hukum yang berlaku.

b. Iklan tidak boleh menyinggung perasaan dan/atau merendahkan martabat, agama, tata susila, adat, budaya, suku dan golongan.

c. Iklan harus dijiwai oleh asas-asas persaingan yang sehat.

Asas-asas umum tersebut kemudian dijabarkan dalam penerapan umum maupun penerapan khusus. Dalam Tata Krama dan dan Tata Cara Periklanan Indonesia tersebut juga diatur tentang hubungan antara unsur-unsur yang berkepentingan dalam periklanan, baik hubungannya dengan konsumen, pengiklan sendiri (perusahaan periklanan), pemerintah dan dengan media. Dalam hubungannya dengan konsumen, maka apabila diminta oleh konsumen, baik perusahaan periklanan, media maupun pengiklan harus bersedia memberikan penjelasan mengenai suatu iklan tertentu. Hal ini terkait dengan hak-hak konsumen.

Keberadaan iklan sebagai sumber informasi, sangat penting bagi konsumen, karena berdasarkan informasi dalam iklan tersebutlah, konsumen memutuskan untuk membeli atau tidak. Berkaitan dengan hak konsumen atas informasi tersebut, maka Pemuatan iklan di Indonesia tidak boleh melanggar Kode Etik Periklanan yang berlaku di Indonesia. Adapun Kode Etik Periklanan secara umum sebagai berikut :

a. Jujur : tidak memuat konten yang tidak sesuai dengan kondisi produk yang diiklankan

b. Tidak memicu konflik SARA

c. Tidak mengandung pornografi

d. Tidak bertentangan dengan norma-norma yang berlaku.

e. Tidak melanggar etika bisnis, misalnya: saling menjatuhkan produk tertentu dan sebagainya.

f. Tidak plagiat

Isi iklan yang dipublikasikan juga tidak boleh menyimpang dari Tata Krama Periklanan Yang sudah diatur dalam Etika Pariwara Indonesia, antara lain adalah:

a. Iklan harus disajikan dalam bahasa yang bisa dipahami oleh khalayak sasarannya, dan tidak menggunakan persandian (enkripsi) yang dapat menimbulkan penafsiran selain dari yang dimaksudkan oleh perancang pesan iklan tersebut.

b. Jika harga sesuatu produk dicantumkan dalam iklan, maka harus ditampakkan dengan jelas, sehingga konsumen mengetahui apa yang akan diperolehnya dengan harga tersebut.

c. Iklan tidak boleh merendahkan produk pesaing secara langsung maupun tidak langsung. 
d. Iklan tidak boleh dengan sengaja meniru iklan produk pesaing sedemikian rupa sehingga dapat merendahkan produk pesaing, ataupun menyesatkan atau membingungkan khalayak. Peniruan tersebut meliputi baik ide dasar, konsep atau alur cerita, setting, komposisi musik maupun eksekusi. Dalam pengertian eksekusi termasuk model, kemasan, bentuk merek, logo, judul atau subjudul, slogan, komposisi huruf dan gambar, komposisi musik baik melodi maupun lirik, ikon atau atribut khas lain, dan properti.

e. Iklan tidak boleh meniru ikon atau atribut khas yang telah lebih dulu digunakan oleh sesuatu iklan produk pesaing dan masih digunakan hingga kurun dua tahun terakhir.

Dalam pembuatan iklan, selain mendasarkan pada Asas-asas umum Tata Krama dan Tata Cara Periklanan, ketentuan tentang beriklan secara tegas diatur dalam Undang Undang Nomor 8 Tahun 1999 tentang Perlindungan Konsumen.

Pasal 9 :

(1) Pelaku usaha dilarang menawarkan, mempromosikan, dan mengiklankan suatu barang dan/atau jasa secara tidak benar dan atau seolah-olah :

a. Barang tersebut telah memenuhi dan/atau memiliki potongan harga, harga khusus, standar mutu tertentu, gaya atau mode tertentu, karakteristik tertentu, sejarah atau guna tertentu;

b. Barang tersebut dalam keadaan baik dan/atau baru;

c. Barang dan/atau jasa tersebut telah mendapatkan dan/atau memiliki sponsor, persetujuan, perlengkapan tertentu, keuntungan tertentu, ciri-ciri kerja, atau asesori tertentu;

d. Barang dan/atau jasa tersebut dibuat oleh perusahaan yang mempunyai sponsor, persetujuan atau afiliasi;

e. Barang dan/atau jasa tersebut tersedia;

f. Barang tersebut tidak mengandung cacat tersembunyi;

g. Barang tersebut merupakan kelengkapan dari barang tertentu;

h. Barang tersebut berasal dari daerah tertentu;

i. Secara langsung atau tidak langsung merendahkan barang dan/atau jasa lain;

j. Menggunakan kata-kata yang berlebihan, seperti aman, tidak berbahaya, tidak mengandung risiko, atau efek samping tanpa keterangan yang lengkap;

k. Menawarkan sesuatu yang mengandung janji yang belum pasti.

Pasal 10 :

Pelaku usaha dilarang menawarkan barang dan/atau jasa yang ditujukan untuk diperdagangkan dilarang menawarkan, mempromosikan, mengiklankan atau membuat pernyataan yang tidak benar atau menyesatkan, mengenai :

a. Harga atau tarif suatu barang dan/atau jasa;

b. Kegunaan suatu barang;

c. Kondisi, tanggungan, jaminan, hak atau ganti rugi atas suatu barang dan/atau jasa;

d. Tawaran potongan harga atau hadiah menarik yang ditawarkan;

e. Bahaya penggunaan barang dan/atau jasa. 


\section{Pasal 12:}

Pelaku usaha dilarang menawarkan, mempromosikan, atau mengiklankan suatu barang dan/atau jasa dengan harga atau tarif khusus dalam waktu dan jumlah tertentu, jika pelaku usaha tersebut tidak bermaksud untuk melaksanakannya sesuai dengan waktu dan jumlah yang ditawarkan, dipromosikan, atau diiklankan.

Pasal 13:

Pelaku usaha dilarang menawarkan, mempromosikan, atau mengiklankan suatu barang dan/atau jasa dengan cara menjanjikan pemberian hadiah berupa barang dan/atau jasa lain secara cuma-cuma dengan maksud tidak memberikannya atau memberikan tidak sebagaimana yang dijanjikan.

Ketentuan Pasal 13 tersebut menunjukkan bahwa pelaku usaha yang sengaja mengelabuhi atau menyesatkan konsumen, walaupun perilaku tersebut baru akan diketahui setelah konsumen yang mengadakan kontrak dengan pelaku usaha mengenai barang dan/atau jasa yang ditawarkan, dipromosikan, atau diiklankan oleh pelaku usaha.

Secara khusus Perbuatan yang dilarang bagi pelaku usaha periklanan diatur dalam Pasal 17 ayat (1), yang menetapkan bahwa pelaku usaha perikalan dilarang memproduksi iklan yang:

a. Mengelabui konsumen mengenai kualitas, kuantitas, bahan, kegunaan, dan harga barang dan/atau tarif jasa serta ketepatan waktu penerimaan barang dan/atau jasa;

b. Mengelabui jaminan/garansi terhadap barang dan/atau jasa;

c. Memuat informasi yang keliru, salah, atau tidak tepat mengenai barang dan/atau jasa;

d. Tidak memuat informasi mengenai risiko pemakaian barang dan/ atau jasa.

e. Mengeksploitasi kejadian dan atau seseorang tanpa seizin yang berwenang atau yang bersangkutan;

f. Melanggar etika dan/atau ketentuan peraturan perundang-undangan mengenai periklanan.

Pasal 17 tersebut merupakan pasal yang secara khusus ditujukan pada perilaku pelaku usaha periklanan, yang mengelabui konsumen melalui iklan yang diproduksinya. Menurut Ari Purwadi, “mengelabui konsumen melalui iklan dapat terjadi dalam bentuk: pernyataan yang salah, pernyataan yang menyesatkan, dan iklan yang berlebihan". 4

Regulasi tentang periklanan dapat juga ditemukan dalam :

a. Undang-undang No.32 Tahun 2002 tentang Penyiaran.

\footnotetext{
${ }^{4}$ Ari Purwadi, "Perlindungan Konsumen dari Sudut Periklanan", Majalah Hukum TRISAKTI, Fakultas Hukum Universitas Trisakti, Jakarta, No. 21/Tahun XXI/Januari/1996, hlm.8. Dalam Ahmadi Miru dan Sutarman Yodo, Op. Cit., hlm. 102.
} 
Dalam Pasal 1 angka 6, yang dimaksud Siaran Iklan Niaga adalah siaran iklan komersial yang disiarkan melalui penyiaran radio atau televisi dengan tujuan memperkenalkan, memasyarakatkan, dan/atau mempromosikan barang atau jasa kepada khalayak sasaran untuk mempengaruhi konsumen agar menggunakan produk yang ditawarkan.

b. Undang-Undang No. 40 Tahun 1999 tentang Pers

Fungsi iklan sebagai sarana penyebarluasan informasi produk telah menempatkan perusahan periklanan maupun media cetak dan elektronik sebagai bentuk-bentuk melaksanakan kegiatan jurnalistik. Hal tersebut dijelaskan pada Pasal 1 angka 1 Undang Undang Pers bahwa yang dimaksud dengan Pers adalah :

"Lembaga sosial dan wahana komunikasi massa yang melaksanakan kegiatan jurnalistik meliputi mencari, memperoleh, memiliki, menyimpan, mengelola dan menyampaikan informasi baik dalam bentuk tulisan, suara, dan gambar, serta data dan grafik maupun dalam bentuk lainnya dengan menggunakan media cetak, media elektronik dan segala jenis saluran yang tersedia."

Dengan adanya ketentuan-ketentuan tersebut diharapkan pelaku usaha periklanan lebih berhati-hati dalam menerjemahkan permintaan pengusaha dalam membuat iklan, sehingga tetap berpedoman pada regulasi yang ada dan tidak melakukan pelanggaran, apalagi yang sampai menimbulkan kerugian kepada konsumen.

\subsection{Iklan yang Merugikan Konsumen}

Salah satu unsur pokok kesejahteraan rakyat adalah terpenuhinya kebutuhan perumahan, yang merupakan kebutuhan dasar bagi setiap Warga Negara Indonesia dan keluarganya, sesuai dengan harkat dan martabatnya sebagai manusia. Di samping itu pembangunan perumahan merupakan salah satu instrumen terpenting dalam strategi pengembangan wilayah yang menyangkut aspek-aspek yang luas dibidang kependudukan dan berkaitan erat dengan pembangunan ekonomi dan kehidupan sosial dalam rangka pemantapan ketahanan nasional.

Dalam Undang-Undang Perumahan dan Permukiman dinyatakan dalam Pasal 1 angka 1 dan 2 bahwa :

"Rumah adalah bangunan yang berfungsi sebagai tempat tinggal, atau hunian dan sarana pembinaan keluarga"

"Perumahan adalah kelompok rumah yang berfungsi sebagai lingkungan tempat tinggal atau hunian yang dilengkapi dengan prasarana dan sarana lingkungan." 
Dapat diketahui bahwa rumah adalah bangunan di mana manusia tinggal dan melangsungkan kehidupannya, di samping itu rumah juga merupakan tempat berlangsungnya proses sosialisasi pada saat seseorang diperkenalkan kepada norma dan adat kebiasaan yang berlaku dalam masyarakat, maka tidaklah mengherankan bila masalah perumahan menjadi masalah yang penting bagi individu. ${ }^{5}$

Seiring dengan semakin pesatnya pembangunan perumahan dan juga semakin ketatnya persaingan di kalangan developer, sehingga banyak cara yang dilakukan developer untuk dapat menjual rumahnya. Salah satu cara yang dilakukan pengembang untuk menawarkan produknya adalah dengan melalui iklan. Iklan adalah merupakan keterangam atau pernyataan produk dalam bentuk gambar, tulisan atau bentuk lainnya. Dengan iklan ini, maka pengusaha dapat mempromosikan barang dan jasa, sebagai usaha untuk meningkatkan omzet penjualan dan meningkatkan keuntungan.

Melalui iklan developer menginformasikan produknya kepada konsumen. Menurut Ahmadi Miru dan Sutarman Yodo, ${ }^{6}$ Hak konsumen atas informasi ini sangat penting, karena tidak memadainya informasi yang disampaikan kepada konsumen, yang disampaikan kepada konsumen ini dapat juga merupakan salah satu cacat produk, yaitu yang dikenal dengan cacat instruksi atau cacat karena informasi yang tidak memadai. Hak atas informasi yang jelas dan benar, dimaksudkan agar konsumen dapat memperoleh gambaran yang benar tentang suatu produk, karena dengan informasi tersebut, konsumen dapat memilih produk yang diinginkan/sesuai kebutuhannya serta terhindar dari kerugian akibat kesalahan dalam penggunaan produk.

Berawal dari informasi yang disampaikan melalui iklan, konsumen memutuskan untuk membeli rumah. Oleh karena itu iklan harus perdoman pada etik dan hukum. Informasi yang disampaikan melalui iklan harus benar dan jujur. Banyaknya iklan yang ditawarkan ternyata menimbulkan banyak masalah, seperti iklan yang membodohi kosumen, bahkan menipu. Seringkali materi dalam iklan perumahan tidak sepenuhnya dapat dipertanggungjawabkan. Iklan sengaja memuat informasi yang menyesatkan, yang tujuan utamanya adalah menarik minat konsumen untuk membeli, dan hal itu dilakukan semata-mata untuk memperoleh keuntungan.

Meskipun sudah ada Undang-Undang Perlindungan Konsumen (UUPK), yang memuat larangan kegiatan periklanan dan Tata Krama dan Tata Cara Periklanan

\footnotetext{
${ }^{5}$ Budihardjo, Sejumlah Masalah Permukinan Kota, Alumni, Bandung, 1992, hlm 145.

${ }^{6}$ Miru, A. dan Yodo, S. Op. Cit., hlm. 41.
} 
Indonesia, namun dalam praktek masih saja ditemui kegiatan periklanan yang bertentangan dengan aturan yang ada dan seringkali menjadi sasaran keluhan dari konsumen karena dianggap tidak jujur (unfair) dan menyesatkan (misleading) atau mengelabui, serta melawan hukum dan kode etik. Banyak iklan yang berkedok sadar lingkungan, tetapi kenyataannya sangat bertolak belakang. ${ }^{7}$

Ada beberapa cara yang digunakan pengembang/developer dalam iklan perumahan untuk menjelaskan lokasi perumahan antara lain :

a. Dengan menggunakan indikator jarak tempuh atau waktu tempuh dari lokasi perumahan;

b. Dengan menggunakan indikator harga, seperti harga terjangkau;

c. Dalam lingkungan strategis, alam segar dan bebas banjir;

d. Dengan menggunakan indikator kualitas bangunan dan lain-lain.

Iklan yang dapat merugikan konsumen dapat berupa bait advertising, blind advertising, dan false advertising. ${ }^{8}$ Secara umum, informasi yang disampaikan kepada konsumen dilakukan dengan cara merepresentasikan suatu produk dengan berbagai cara dengan berbagai media, namun dalam pelaksanaannya kadang terjadi misrepresentasi. ${ }^{9}$ Misrepresentasi merupakan pernyataan tidak benar yang dilakukan oleh suatu pihak untuk membujuk pihak lain masuk dalam suatu perjanjian. Dengan demikian, masalah dasar dari misrepresentasi adalah dampak dari suatu pernyataan yang disampaikan sebelum terjadinya perjanjian. ${ }^{10}$

Di bawah ini penulis berikan contoh iklan yang tidak sesuai dengan janji yang dapat menimbulkan kerugian kepada konsumen. Wahyu Ardianto memutuskan untuk membeli satu unit rumah Tipe 36/72 di Rivera Hils Cinangka Depok, Jawa Barat, seharga Rp 235.000.000 (dua ratus tiga puluh lima juta rupiah) sudah termasuk biaya balik nama Sertifikat Hak Milik dan Izin Mendirikan Bangunan, karena janji iklan yang disampaikan oleh developer. Kenyataannya rumah tidak selesai dibangun sesuai janjinya. Bahkan pembangunan perumahan Rivera Hills telah diambil alih oleh developer lain. Setelah developer yang baru didatangi, barulah rumah tersebut diselesaikan. Pada saat penyerahan, Wahyu menerima Sertifikat Hak Guna Bangunan

\footnotetext{
${ }^{7}$ Syawali, H. Hukum Perlindungan Konsumen. 2000. Bandung: Mandar Maju hal 60.

${ }^{8}$ Miru, A dan Yodo, S. Op. Cit.,hlm. 105.

${ }^{9}$ Ibid.,hlm. 105-106, sebagaimana dikutip dari F.R. Davies. 1970. Contract. London: Sweet \& Maxwell, hlm. 82.

${ }^{10}$ Ibid.,hlm. 106, sebagaimana dikutip dari G.C. Cheshire and Filoot, C.H.S. 1981. The Law of Contract, Fourth Australian Edition, by Higgins, P.F.P., et al. Sidney: Bulterworths hlm. 253.
} 
(SHGB), padahal perjanjian diawal, bukti legalitas yang diterimanya seharusnya Sertifikat Hak Milik (SHM).

Dari kasus iklan yang dibuat oleh developer, ternyata banyakhal yang tidak dipenuhi oleh developer, diantaranya: tidak dipenuhi batas waktu penyelesaian rumah; tidak dipenuhinya Sertifikat Hak Milik langsung atas nama pembeli. Hal tersebut jelas, bahwa pihak developer telah membuat iklan yang tidak benar dan merugikan konsumen.

\subsection{Penyelesaian Sengketa Konssumen Perumahan dan Pemukiman}

Perlindungan konsumen perumahan adalah serangkaian upaya yang dibingkai secara hukum, untuk melindungi konsumen perumahan sebagai pengguna fasilitas perumahan, yang meliputi fasilitas bangunan (konstruksi) yang sesuai standar, fasilitas lingkungan, fasilitias sosial, fasilitas umum dan memenuhi standar kesehatan, serta mampu memberi rasa aman kepada penghuninya, baik itu untuk kepentingan pribadi, keluarga, institusi ataupun pihak lain, tetapi tidak untuk diperdagangkan kembali.”

Menurut Pasal 3 Undang-Undang Perlindungan Konsumen, Perlindungan Konsumen bertujuan untuk:

a. Meningkatkan kesadaran, kemampuan dan kemandirian konsumen untuk melindungi diri

b. Mengangkat harkat dan martabat konsumen dengan cara menghindarkannya dari ekses negative pemakaian barang dan atau jasa

c. Meningkatkan pemberdayaan konsumen dalam memilih, menentukan dan menuntut hak-haknya sebagai konsumen

d. Menciptakan sistem perlindungan konsumen yang mengandung unsur kepastian hukum, keterbukaan informasi serta akses untuk mendapatkan informasi

e. Menumbuhkan kesadaran pelaku usaha mengenai pentingnya perlindungan konsumen, sehingga tumbuh sikap jujur dan bertanggung jawab dalam berusaha

f. Meningkatkan kualitas barang dan atau jasa yang menjamin kelangsungan usaha produksi barang dan atau jasa, kesehatan, kenyamanan, keamanan dan keselamatan konsumen

Hak-hak Konsumen yang diatur dalam Pasal 4 Undang-Undang Perlindungan Konsumen, yakni:

1. Hak atas kenyamanan, keamanan dan keselamatan dalam mengkonsumsi barang dan/atau jasa.

2. Hak untuk memilih barang dan/atau jasa serta mendapatkan barang dan/atau jasa tersebut sesuai dengan nilai tukar dan kondisi serta jaminan yang dijanjikan

3. Hak atas informasi yang benar, jelas dan jujur mengenai kondisi dan jaminan barang dan/atau jasa

4. Hak untuk didengar pendapat dan keluhannya atas barang dan/atau jasa yang digunakan. 
5. Hak untuk mendapatkan advokasi, perlindungan dan upaya penyelesaian sengketa perlindungan konsumen secara patut.

6. Hak untuk mendapat pembinaan dan pendidikan konsumen.

7. Hak untuk diperlakukan atau dilayani secara benar dan jujur serta tidak diskriminatif.

8. Hak untuk mendapatkan kompensasi, ganti rugi, dan/atau penggantian, apabila barang dan/atau jasa yang diterima tidak sesuai dengan perjanjian atau tidak sebagaimana mestinya.

9. Hak-hak yang diatur dalam ketentuan perundang-undangan lainnya.

Hak-hak konsumen yang tersebut diatas berguna untuk melindungi kepentingan konsumen, sebagaimana tercantum dalam tujuan dari perlindungan konsumen yaitu mengangkat harkat hidup dan martabat konsumen. Sehingga diharapkan konsumen menyadari akan hak-haknya dan pelaku usaha diharuskan untuk memperhatikan apa saja perbuatan-perbuatan usaha yang dilarang menurut Undang-Undang Perlindungan Konsumen, sehingga tidak ada lagi pelanggaran hak-hak konsumen.

Selain mempunyai hak, konsumen juga memiliki beberapa kewajiban. Kewajiban adalah suatu beban atau tanggungan yang bersifat kontraktual. Dengan kata lain kewajiban adalah sesuatu yang sepatutnya diberikan. ${ }^{11}$ Kewajiban konsumen sesuai dengan Pasal 5 Undang-Undang Perlindungan Konsumen, yaitu:

a. Membaca atau mengikuti petunjuk informasi dan prosedur pemakaian atau pemanfaatan barang dan/atau jasa, demi keamanan dan keselamatan

b. Beritikad baik dalam melakukan transaksi pembelian barang dan/atau jasa

c. Membayar sesuai dengan nilai tukar yang disepakati

d. Mengikuti upaya penyelesaian hukum sengketa perlindungan konsumen secara patut

Perlindungan terhadap konsumen yang diberikan dalam Undang Undang Perlindungan Konsumen, diwujudkan dengan adanya ketentuan yang mengatur tentang:

a. Perbuatan dan kewajiban dari para pihak.

b. Perbuatan yang dilarang bagi pelaku usaha

c. Klausula baku

d. Tanggung jawab hukum

e. Penyelesaian sengketa

f. Sanksi

Upaya pengembangan perlindungan konsumen sebagaimana diamanatkan oleh Undang-Undang Perlindungan Konsumen dan Peraturan Pemerintah No. 57 Tahun 2001

\footnotetext{
${ }^{11}$ Perlindungan Konsumen dan Peraturan Perundang-undangan yang terkait. 2006. Bandung. Penerbit Nuanasa Aulia, hal 37.
} 
tentang Badan Perlindungan Konsumen Nasional yang menjadi dasar didirikannya Badan Perlindungan Konsumen Nasional. Tugas Utama BPKN diantaranya adalah: ${ }^{12}$
a. Memberikan saran dan rekomendasi kepada pemerintah dalam rangka penyusunan kebijaksanaan di bidang perlindungan konsumen,
b. Melakukan penelitian dan pengkajian terhadap peraturan perundang-undangan yang berlaku di bidang perlindungan konsumen,
c. Melakukan penelitian terhadap barang dan/atau jasa yang menyangkut keselamatan konsumen,
d. Mendorong berkembangnya lembaga perlindungan konsumen swadaya masyarakat,
e. Menyebarluaskan informasi melalui media mengenai perlindungan konsumen dan memasyarakatkan sikap keberpihakan kepada konsumen,
f. Menerima pengaduan tentang perlindungan konsumen dari masyarakat, lembaga perlindungan konsumen swadaya masyarakat atau pelaku usaha; dan
g. Melakukan survei yang menyangkut kebutuhan konsumen.

Dalam menganalisa perlindungan hukum bagi rakyat Indonesia, Philipus M. Hadjon mengatakan: ${ }^{13}$

Perlindungan hukum adalah perlindungan akan harkat dan martabat, serta pengakuan terhadap hak-hak asasi manusia yang dimiliki oleh subyek hukum berdasarkan ketentuan hukum. Perlindungan hukum bagi rakyat dapat dibagi menjadi dua, yaitu: 1) perlindungan preventif dimana rakyat diberikan kesempatan untuk mengajukan keberatan (inspraak) atau pendapatnya sebelum suatu keputusan pemerintah mendapat bentuk yang definitive, artinya perlindungan hukum preventif bertujuan mencegah timbulnya sengketa. 2) perlindungan hukum represif bertujuan untuk menyelesaikan sengketa.

Perlindungan hukum konsumen secara preventif dapat dilakukan dengan pembinaan terhadap konsumen, agar konsumen tidak terperangkap dalam kerugian yang dialami akibat posisi tawar yang tidak seimbang. YLKI mewadahi aspirasi perkumpulan konsumen di Indonesia, dapat melakukan pembinaan terhadap konsumen perumahan yang akan melakukan transaksi di bidang perumahan. YLKI dapat memberikan penyuluhan terkait kehati-hatian serta ketelitian konsumen dalam melakukan kesepakatan dengan pengembang baik pada tahap prakontraktual, tahap kontraktual maupun tahap pasca kontraktual. Selain peran pembinaan konsumen diatas, YLKI juga memiliki peran dalam mensosialisasikan upaya yang dapat dilakukan konsumen ketika menghadapi sengketa. Seringkali konsumen mengalami ketidaktahuan mengenai hak-

\footnotetext{
${ }^{12}$ Direktorat Pemberdayaan Konsumen, Lembaga Penyelenggaraan Perlindungan Konsumen, http://ditjenspk.kemendag.go.id/id/direktorat-pemberdayaan-konsumen/kelembagaan, diakses 3 Juli 2017.

${ }^{13}$ Philipus M. Hadjon, Perlindungan Hukum Bagi Rakyat di Indonesia, Bina Ilmu, Surabaya, 1987, h. 2.
} 
hak yang dapat dilakukan apabila terjadi kerugian yang dikarenakan perbuatan developer/pelaku usaha. Akibat tidak terpenuhinya janji dalam iklan, yang menimbulkan kerugian, konsumen mempunyai hak untuk menyelesaikan sengketanya.

Perlindungan hukum secara represif merupakan perlindungan hukum yang dapat diberikan setelah terjadinya sengketa. Menurut Ahmadi Miru ${ }^{14}$, dalam dunia bisnis, penyelesaian sengketa yang dikehendaki adalah yang dapat berlangsung cepat dan murah. Selain itu, penyelesaian sengketa dalam dunia bisnis diharapkan sedapat mungkin tidak merusak hubungan bisnis selanjutnya dengan siapa dia pernah terlibat suatu sengketa.

Perlindungan hukum represif dalam penyelesaian sengketa konsumen, pada dasarnya dapat dilakukan melalui penyelesaian di luar pengadilan (non litigasi) dan melalui peradilan (litigasi). Hal tersebut, sesuai dengan ketentuan Undang-Undang Nomor 8 tahun 1999 tentang Perlindungan Konsumen, yang menyatakan bahwa penyelesaian sengketa dibagi menjadi dua, yaitu penyelesaian sengketa di luar pengadilan dan penyelesaian sengketa di pengadilan.

Lembaga yang menangani penyelesaian sengketa di luar pengadilan dalam Undang Undang Perlindungan Konsumen adalah "Badan Penyelesaian Sengketa Konsumen (BPSK)" yang diatur dalam Pasal 49 ayat (1). BPSK yang merupakan suatu lembaga khusus yang dibentuk dan diatur dalam Undang-Undang Perlindungan Konsumen, tugas utamanya adalah melaksanakan penanganan dan penyelesaian sengketa konsumen dengan cara melalui Mediasi, Konsiliasi atau Arbitrase.

Menurut Undang-Undang Nomor 1 Tahun 2011 Tentang Perumahan dan Kawasan Pemukiman, pada pasal 147 Penyelesaian sengketa di bidang perumahan terlebih dahulu diupayakan berdasarkan musyawarah untuk mufakat.

Dipilihnya penyelesaian secara musyawarah mufakat dan penyelesaian di luar pengadilan, karena proses penyelesaian sengketa melalui pengadilan (litigasi), akan berakhir dengan kekalahan salah satu pihak dan kemenangan pihak lainnya pihak lainnya, ${ }^{15}$ proses peradilan yang berlangsung lama dan membutuhkan biaya yang tidak sedikit.

Alasan yang sering dikemukakan, dipilihnya penyelesaian sengketa di luar pengadilan, karena ingin memangkas birokrasi perkara, biaya dan waktu, sehingga

\footnotetext{
${ }^{14}$ Ahmadi Miru, Prinsip-prinsip Perlindungan Hukum Bagi Konsumen Di Indonesia, Cetakan ke 2, RajaGrafindo Persada, Jakarta, 2013, hlm. 155.

${ }^{15}$ Ahmadi Miru, Loc. Cit.
} 
relatif lebih cepat dengan biaya yang ringan, lebih dapat menjaga harmoni sosial dengan mengembangkan budaya musyawarah dan budaya nonkonfrontatif. Melalui penyelesaian tersebut diharapkan tidak terjadi prinsip lose-win tetapi win-win, para pihak merasa menang sehingga menghindarkan terjadinya hard feeling dan loosing face.

Penyelesaian sengketa di luar pengadilan atau yang lebih dikenal dengan Alternative Dispute Resolution (ADR), ditempuh dengan berbagai cara. ADR tersebut dapat berupa arbitrase, mediasi, konsiliasi, minitrial, summary jury trial, settlement conference serta bentuk lainnya. ${ }^{16}$

Dalam Pasal 1 Undang Undang Nomor 30 Tahun 1999 tentang Arbitrase dan Alternatif Penyelesaian Sengketa, arbitrase dibedakan dari alternative penyelesaian sengketa, karena yang termasuk dalam alternatif penyelesaian sengketa hanya konsultasi, negosiasi, mediasi, dan penilaian ahli. ${ }^{17}$

Meskipun terdapat berbagai cara yang dapat ditempuh untuk menyelesaikan sengketa di luar pengadilan, namun yang dibahas dalam makalah ini hanya mediasi, konsiliasi dan arbitrase sebagaimana dikenal dalam Undang-Undang Perlindungan Konsumen.

\section{a. Mediasi.}

Mediasi merupakan cara penyelesaian sengketa yang fleksibel dan tidak mengikat serta melibatkan pihak netral, yaitu mediator, yang memudahkan negosiasi antara para pihak/membantu mereka dalam mencapai kompromi/kesepakatan. Mediasi merupakan proses negosiasi pemecahan masalah di mana pihak luar yang tidak memihak (impartial) bekerja sama dengan pihak yang bersengketa untuk membantu memperoleh kesepakatan perjanjian dengan memuaskan. Mediator tidak berwenang untuk memutuskan perkara atau sengketa, tapi tergantung pada para pihak yang bersengketa. Hasil dari suatu mediasi dapat dirumuskan dengan cara lisan ataupun tertulis, yang tidak secara mutlak mengakiri sengketa secara final, karena dapat dianggap sebagai suatu perjanjian baru atau dapat juga dijadikan sebagai suatu perdamaian.

\section{b. Konsiliasi.}

\footnotetext{
${ }^{16}$ Yahya Harahap, Beberapa Tinjauan Mengenai Sistem Peradilan dan Penyelesaian Sengketa, Citra Aditya Bakti, Bandung, 1997, hlm. 186.

${ }^{17}$ Ahmadi Miru, Op. Cit., hlm. 159.
} 
Konsiliasi merupakan salah satu alternatif penyelesaian sengketa di luar pengadilan, yang diartikan sebagai : an independent person (conciliator) brings the parties together and encourages a mutualy acceptable resolution of the dispute by facilitating communication between the parties. ${ }^{18}$ Penyelesaian sengketa ini hampir sama dengan arbitrase, menyerahkan kepada pihak ketiga untuk memberikan pendapatnya. Namun pendapat konsiliator tidak mengikat. Penyelesaiannya sangat tergantung pada kesukarelaan para pihak.

Ketentuan mengenai konsiliasi terdapat dalam Pasal 1 ayat 10 dan alenia ke-9 Penjelasan Umum Undang-Undang nomor 30 tahun 1999. Hasil dari kesepakatan para pihak melalui alternatif penyelesaian sengketa konsiliasi harus dibuat secara tertulis dan ditandatangani secara bersama oleh para pihak yang bersengketa. Kesepakatan tertulis dari konsiliasi ini bersifat final dan mengikat para pihak.

\section{c. Arbitrase.}

Arbitrase adalah cara penyelesaian sengketa perdata di luar pengadilan yang didasarkan pada perjanjian arbitase yang dibuat oleh para pihak yang bersengketa. Penyelesaian sengketa melalui arbitrase dapat dilakukan oleh para pihak yang bersengketa, jika para pihak tersebut telah mencantumkan klausul arbitrase dalam perjanjian yang menjadi pokok sengketa atau mengadakan perjanjian arbitrase setelah timbulnya sengketa di antara mereka. Penyelesaian sengketa melalui arbitrase, putusannya adalah final dan mempunyai kekuatan hukum tetap dan mengikat para pihak. Putusan arbitrase ini, memiliki kekuatan eksekutorial, sehingga apabila pihak yang dikalahkan tidak memenuhi putusan secara sukarela, maka pihak yang menang dapat meminta eksekusi ke Pengadilan.

Apabila penyelesaian sengketa di luar pengadilan tidak tercapai, maka dapat diselesaikan melalui pengadilan atau litigasi. Penyelesaian sengketa melalui pengadilan dilakukan oleh pengadilan niaga.Ketentuan peran represif pengadilan niaga terdapat pada Pasal 45 dan Pasal 46 Undang-Undang Perlindungan Konsumen. Berdasarkan ketentuan tersebut setiap konsumen yang dirugikan dapat menggugat pelaku usaha melalui lembaga yang bertugas menyelesaikan sengketa antara konsumen dan pelaku usaha atau melalui peradilan yang berada di lingkungan peradilan umum berdasarkan

\footnotetext{
${ }^{18}$ Lamuel W. Dowdy, et. Al., Prepared by Consumer Dispute Resolution Program Staff Attoeneys, Federal Trade Commission-Division of Product Reliability, Washinton, D.C., hlm. 5. tt. Dalam Ahmadi Miru, Op. Cit., hlm. 162.
} 
pilihan sukarela para pihak yang bersengketa. Gugatan atas pelanggaran pelaku usaha dapat dilakukan oleh konsumen yang dirugikan maupun ahli waris yang bersangkutan, kelompok konsumen yang mempunyai kepentingan yang sama, lembaga perlindungan konsumen swadaya masyarakat yang memenuhi syarat serta pemerintah dan/atau instansi terkait apabila barang dan/atau jasa yang dikonsumsi atau dimanfaatkan mengakibatkan kerugian materi yang besar dan/atau korban yang tidak sedikit.

Pasal 45 ayat 1 sampai 4 Undang-Undang Perlindungan Konsumen, menyatakan:

1. Setiap konsumen yang dirugikan dapat menggugat pelaku usaha melalui lembaga yang bertugas menyelesaikan sengketa antara konsumen dan pelaku usaha atau melalui peradilan yang berada di lingkungan peradilan umum.

2. Penyelesaian sengketa konsumen dapat ditempuh melalui pengadilan atau di luar pengadilan berdasarkan pilihan sukarela para pihak yang bersengketa.

3. Penyelesaian sengketa di luar pengadilan sebagaimana dimaksud pada ayat (2) tidak menghilangkan tanggungjawab pidana sebagaimana diatur dalam UndangUndang.

4. Apabila telah dipilih upaya penyelesaian sengketa konsumen di luar pengadilan, maka gugatan melalui pengadilan hanya dapat ditempuh apabila upaya tersebut dinyatakan tidak berhasil oleh salah satu pihak atau oleh pihak yang bersengketa.

Dari pernyataan pasal 45 ayat 4 , meskipun sudah dipilih upaya penyelesaian sengketa di luar pengadilan, apabila mediator dan konsiliator tidak berhasil mengantar para pihak mencapai kesepakatan dalam mediasi dan konsiliasi atau belum berhasil memberi putusan dalam arbitrase, maka masih memberikan kesempatan untuk mengajukan gugatan ke pengadilan.

Sebagai bentuk perlindungan hukum kepada konsumen, agar dapat menyelesaikan sengketa secara lebih cepat, selain melalui Badan Penyelesaian Sengketa Konsumen, juga dikenal class action, yaitu suatu prosedur hukum yang memungkinkan banyak orang bergabung untuk menuntut ganti kerugian atau kompensasi lainnya di dalam suatu gugatan. ${ }^{19}$

Ketentuan hukum yang menjadi dasar gugatan class action (gugatan kelompok) terdapat dalam Pasal 46 Undang Undang Perlindungan Konsumen. Yang dapat mengajukan gugatan ke pengadilan adalah:

a. seorang konsumen yang dirugikan atau ahli waris yang bersangkutan;

b. kelompok konsumen yang mempunyai kepentingan yang sama;

c. lembaga perlindungan konsumen swadaya masyarakat yang memenuhi syarat, yaitu berbentuk badan hukum atau yayasan, yang dalam anggaran

\footnotetext{
${ }^{19}$ Rachagan, S. S. (ed). Consumer Access to Justice, an Overview, in Develeping Consumers Law in Asia, IOCU Regional Office for Asia and the Pasific, Malaysia, tt., hlm. 207.
} 
dasarnya menyebutkan dengan tegas bahwa tujuan didirikannya organisasi tersebut adalah untuk kepentingan perlindungan konsumen dan telah melaksanakan kegiatan sesuai dengan anggaran dasarnya;

d. pemerintah atau instansi terkait apabila barang atau jasa yang dikonsumsi atau dimanfaatkan mengakibatkan kerugian materi yang besar atau korban yang tidak sedikit

\section{Kesimpulan}

Salah satu upaya yang dilakukan pengembang/developer perumahan untuk menarik minat konsumen adalah dengan cara mengiklankan perumahan tersebut. Masih banyak pelaku usaha periklanan yang melanggar peraturan tentang periklanan. Agar pelaku usaha tidak melakukan perbuatan yang merugikan konsumen perumahan seperti membuat periklanan yang palsu atau iklan yang tidak sesuai dengan kenyataannya, harus berpedoman: Asas-asas umum Periklanan; Tata Krama dan dan Tata Cara Periklanan; Undang Undang Perlindungan Konsumen dan regulasi lainya yang terkait dengan periklanan.

Perlindungan hukum terhadap konsumen perumahan, agar terhindar dari ulah developer yang dapat menimbulkan kerugian adalah dengan upaya perlindungan preventif, dan perlindungan represif. Perlindungan preventif adalah upaya pencegahan sebelum terjadinya sengketa, sedangkan perlindungan represif yaitu memberikan kesempatan kepada konsumen untuk penyelesaian sengketa antara para pihak, baik yang diselesaikan melalui jalur di luar pengadilan atau melalui pengadilan. 


\section{Daftar Pustaka}

Budihardjo. 1992. Sejumlah masalah Permukinan Kota. Bandung: Alumni

Dowdy, L. W. et. Al,. Prepared by Consumer Dispute Resolution Program Staff Attoeneys. Washington, D.C: Federal Trade Commission-Division of Product Reliability,.

Davies, F. R. 1970. Contract. London: Sweet \& Maxwell

G.C. Cheshire and Filoot, C.H.S. 1981. The Law of Contract, Fourth Australian Edition, by Higgins, P.F.P., et al.,. Sidney: Bulterworths.

Harahap, Y. 1997. Beberapa Tinjauan Mengenai Sistem Peradilan dan Penyelesaian Sengketa. Bandung: Citra Aditya Bakti.

Hadjon, P. M. 1987. Perlindungan Hukum Bagi Rakyat di Indonesia. Surabaya: Bina Ilmu.

Miru, A. dan Sutarman, Y. 2004. Hukum Perlindungan Konsumen. Jakarta: Raja Grafindo Persada.

Miru, A. 2013. Prinsip-prinsip Perlindungan Hukum Bagi Konsumen Di Indonesia, Cetakan ke 2. Jakarta: RajaGrafindo Persada.

Purwadi, A. 1992. Aspek Hukum Perdata Pada Perlindungan Konsumen". Surabaya:Yuridika, Fakultas Hukum Universitas Airlangga.

Purwadi, A. 1996. Perlindungan Konsumen dari Sudut Periklanan. Jakarta: Majalah Hukum TRISAKTI, Fakultas Hukum Universitas Trisakti No. 21/Tahun XXI/Januari/1996.

Rachagan, S. S. (ed), Consumer Access to Justice, an Overview, in Develeping Consumers Law in Asia, IOCU Regional Office for Asia and the Pasific, Malaysia, tt.

Syawali, H. 2000. Hukum Perlindungan Konsumen. Bandung: Mandar Maju.

........ 2006. Perlindungan Konsumen dan Peraturan Perundang-undangan yang terkait. Bandung: Penerbit Nuanasa Aulia.

Direktorat Pemberdayaan Konsumen, Lembaga Penyelenggaraan Perlindungan Konsumen, $\quad$ http://ditjenspk.kemendag.go.id/id/direktorat-pemberdayaankonsumen/kelembagaan, diakses 3 Juli 2017 